\title{
A proposal for a new pial arteriovenous fistulas grading scale for neuroendovascular procedures and literature review
}

\author{
Luis Rafael Moscote-Salazar ${ }^{1}$, Hernando Raphael Alvis-Miranda ${ }^{2}$ \\ ${ }^{1}$ Department of Neurological Endovascular Therapy, Instituto Nacional de Neurología y \\ Neurocirugía; México City, México, mineurocirujano@aol.com \\ ${ }^{2}$ Universidad de Cartagena, Cartagena de Indias, Colombia
}

\begin{abstract}
Pial arteriovenous fistulas are an unusual type of cerebrovascular lesion. The vascular supply of this type of injury comes from cortical and pial vessels which are not located in the dura leaflets. With the aim to make a grading scale for this type of injury, we conducted a literature search using the keywords "pial arteriovenous fistulas", "embolization" associated with "outcome". Angiographic and imagenological characteristics typically found in pial arteriovenous fistulas were taken and was developed a preliminary classification system that must be validated in future studies. Pial arteriovenous fistulas are associated with a poor natural history and the establishment of an individualized therapeutic strategy can provide a good prognosis. The endovascular management of these lesions is safe and effective.
\end{abstract}

Key words: pial arteriovenous fistulas, embolization, outcome.

\section{Introduction}

Pial arteriovenous fistulas (PAVF) are a rare type of intracranial arteriovenous lesions, with clinical relevance, $(1,2)$ that recently have been recognized as different from arteriovenous malformations (AVM). (3) PAVF differ from dural arteriovenous fistulas in that their arterial supply derive from pial and cortical arteries and they are not involved by the leaflets of the duramater.

They can have one or multiple arterial conections with only one venous channel, without an intervening nidus or capillary. PAVF can be located in any cerebral region, but usually shown preference for supratentorial regions. (4)

PAVF can be acquired traumatically, iatrogenically or can be congenital lesions. Due to its unfavorable natural course, the conservatory management its associated with a mortality rate up to $63 \%$. (5) Because of the nidus abscense the shunt closure by endovascular or surgical approaches represents a satisfactory therapeutical procedures. (6) At presentation, can be hemorrhages, seizures, focal déficits, and heart failure in neonates, headache and symptoms of raised intracranial pressure, mass effect, palpable masses, cranial erosions and macrocephaly.

This type of fistulas can receive diverse endovascular treatments, currently, due to the scarce cases reported, a classification pointing the type of endovascular approaches needed is absent. We propose a classification using factors already deemed as significant determinants of risk and outcome for endovascular PAVF patients. The classification scheme proposed is very practical in clinical use. 
New pial arteriovenous fistulas grading scale

\section{Methods}

A literature search was performed in several medical databases including Medline, showing a total of 33 results using the keywords "pial arteriovenous fistulas", "embolization", associated with "outcome".

Emphasis was given to the angiographic, imaginologic and hemodynamic characteristics found usually in PAVF because these can be easily adapted to the management established for each particular patient; and was developed a preliminary grading scale that needs be applied in future studies to be validated. The resulting articles were assessed by considering factors such as: age, gender, clinical presentation, and aneurysm or varyx association.

\section{Results}

From the search of 33 articles, emphasis was given to the angiographic, imaginologic and hemodynamic characteristics found usually in PAVF because these can be easily adapted to the management established for each particular patient, as mentioned previously. 23 articles were found. In Table 1 are summarized the main factors associated with impact on the natural course of PAVF, that we consider determinant as variable for grading score.

\section{Age}

Hetts et al., (7) through a retrospective review of a neurointerventional database, identified 386 pediatric patients with intracranial AVFs and AVMs, from which 25 had PAVF. They found that PAVF constituted $7.3 \%$ of pediatric intracranial vascular lesions with a nondural arteriovenous shunt; single-hole fistulas predominate later in childhood and more frequently presented with seizures, hemorrhage, or focal neurologic deficits. In pediatrics patients, the age is a relevant factor, in these same review by Hetts et al.,(7) they found that patients $\leq 2$ years of age compared with patients presenting at $>2$ years of age had more treatment procedures $(\mathrm{P}=.041)$, as in those harboring a multi-hole fistula versus those with a single-hole fistula $(\mathrm{P}=.003)$; patients $\leq 2$ years of age were also more likely to have a multi-hole fistula $(100 \%$ versus $25 \%, \mathrm{P}=.0001$ ) and to have a poor clinical outcome $(54 \%$ versus $0 \%, \mathrm{P}=$ .0052 ), defined as a pediatric $\mathrm{mRS}$ of $\geq 3$.

\begin{tabular}{|c|c|c|}
\hline Variable & Characteristics & Value \\
\hline \multirow{2}{*}{ - Calcification } & Yes & 1 \\
\hline & $\mathrm{No}$ & 0 \\
\hline \multirow{2}{*}{ - Aferences } & Unique & 1 \\
\hline & Multiple & 2 \\
\hline \multirow{2}{*}{ - Location } & Eloquent área & 1 \\
\hline & Non-eloquent área & 0 \\
\hline \multirow{2}{*}{$\begin{array}{c}\text { - Associated } \\
\text { AVM }\end{array}$} & Yes & 1 \\
\hline & No & 0 \\
\hline \multirow{4}{*}{ - Varix } & $>5 \mathrm{cms}$ & 3 \\
\hline & $3-5 \mathrm{cms}$ & 2 \\
\hline & $<3 \mathrm{cms}$ & 1 \\
\hline & No & 0 \\
\hline \multicolumn{3}{|c|}{$\begin{array}{l}\text { Interpretation: Type I: 2-3; Type II: 4-6; Type } \\
\text { III: 7-8. } \\
\text { AVM: arteriovenous malformation } \\
\text { Eloquent area: visual cortex, motor-sensitive } \\
\text { cortex, hypothalamus, thalamus, intern capsule, } \\
\text { brainstem, crux cerebri, or cerebellar nucleus. }\end{array}$} \\
\hline
\end{tabular}

\section{Varix}

Varix formation is a special finding in patients with pial AVF. Some reports suggest that the high pressure blood flow from arterial feeder directly into the venous drainage may result in venous varix formation. (8-12) Yang et al., (13) determined that patients presented at younger age ( $\leq 15$ years old) are more likely 
to have varix in angiographic study $(\mathrm{p}<0.05)$ compared with the adult population, being the clinical presentation different in these two groups. Younger patients are more likely to have symptom related to shunting effect; however, haemorrhage is the major presentation in older patients. Furthermore, the absence of varix do have significant correlation with haemorrhage $(p=0.001)$. However, it is necessarily to remember that patients with PAVF may manifest differently according to their age and the existence of varix. This later might exerts a buffer effect to tolerate the high arterial flow pressure and consequently decrease the risk of bleeding. Much less frequently, there is also an aneurysm of the feeding artery. (11)

\section{Calcification}

It is important to consider the presence of associated calcification, which is more probable in pial than dural arteriovenous lesions. The mechanism of calcification in these lesions is a dystrophic process due to hypoperfusion caused by steal phenomenon or venous congestion over a long time,(2) when mural calcification is thick, it implies a longstanding course of cerebral damage. In these circumstances, even when is feasible the obliteration trough endovascular methods, alleviating the mass effect could be impossible; furthermore, perform first an endovascular approach, and in a second stage surgical removal could be tricky when compared to a single operation for occluding the accessible feeder artery and removing the mass simultaneously. Another fact to consider is that the calcified shell would physically restrict approach and handling of endovascular devices.(2)

\section{Arteriovenous malformation}

PAVF inducing dural arteriovenous shunts (DAVS) have been proposed particularly in some high-flow PAVF associated with DAVS upstream from their drainage into the dural sinus. (14) This could be caused by a similar sump effect created by the high-flow venous drainage of the PAVF downstream. (15) The venous changes produced by high-flow pial AVS on the venous sinuses, such as increased venous pressure or venous outflow obstruction, can also be triggering factors. (15) But this is not the situation in our cases, because they were high-flow DAVSs anatomically closely related to the pial AVFs that were upstream from the DAVSs. The dominant shunts in our cases were highflow DAVS rather than PAVF. (15)

Endovascular therapy of intracranial dural arteriovenous fistula may be curative but is often complex and carries definite risks. Neurosurgical ligation of pial draining veins, with pre-operative embolization when safe, may be a relatively more controlled method to achieve complete cure. (16)

\section{Location}

Lesions in deep and eloquent locations can be associated with a high surgical risk for neurologic morbidity. (17)

\section{Outcome}

Lv et al., (17) reviewed the clinical and radiologic data of 16 patients with PAVF who were treated endovascularly at the Beijing Tiantan Hospital between 1998 and 2008. At the time of the last follow-up evaluation (range, 3-12 months; median, 7 months), 15 patients (93.75\%) had a Glasgow outcome score of $\mathrm{V}$ and 1 patient $(6.25 \%)$ had a Glasgow outcome score of IV. Altogether, there were three perioperative complications (18.75\%). During the follow-up period (range, 3-12 months; mean, 7.4 months), the overall morbidity rate was $6.25 \%$. 
Hydrocephalus caused by venous thrombosis is the main complication, thus heparin should be given routinely after endovascular embolization. $(17,18)$

\section{Pathophysiology}

Although they account for only $1.6 \%$ of all AVM are associated with a poor natural history. Patients with PAVF, and specially infants, are known to develop hydrovenous disorders that rapidly damage the surrounding brain, others alterations include subependymal or cortical atrophy, white matter calcification and delayed myelinization; thus early intervention is essential for optimal neurological and cognitive development. $(4,19)$

Intracranial PAVFs differ from AVM owing to the lack of nidus and from dural arteriovenous fistulas in that they derive their arterial supply from pial or cortical arterial vessels, and the lesion does not lie within the dural leaflets. (8) The abnormality from a PAVF arises from its high-flow nature. The origin of PAVFs can be traumatic, iatrogenic, or congenital. (4) Congenital pAVFs are usually present in childhood. PAVF are considered to be congenital in nature. (20) however, there is little evidence that the PAVF diagnosed in adults are present in the same form at birth. In addition, cases of de novo PAVF have been reported. (21-24)

Little is known about the pathophysiological development mechanism ofthese lesions, but probably are produced by a misstep in the embryological development of the cerebrovasculature, $(4,25)$, also, abnormal angiogenesis and associated vascular growth factors and cytokines may play a role. (4)

Lasjaunias (19) proposed that the congenital event is primarily involving the vascular modeling and remodeling process at the cellular and structural level, affecting the endothelial cells at the venous side of the capillaries, resulting in a progressive dysfunction, and its manifestations will be related with the triggers, such as mechanical, hormonal, pharmacologic, hemodynamic, thermal, radiation, viral, infective, and metabolic factors.

The frequency of venous varices and vessel ectasia, not to mention the association of syndromes that embrace angiodysplasia, (26) may reflect an inherent predilection of dysplastic elements toward the formation of such lesions. (4) The diverse nature and timing of the various triggers causes the different time and form of presentation of the abnormal arteriovenous shunts. The previous postulation can be applied to the acquired lesions, in which the trigger is applied for a certain length of time and had the same consequence on the target cells related to venous vascular remodeling.

The pathogenesis of PAVF also includes abnormal expression of various angiogenic factors such as vascular endothelial growth factor, basic fibroblast growth factor, and alpha transforming growth factor. (27-30) Suppression of vascular cell growth modulators, including endoglin1, has also been found. (31) As have been learned from cases of acquired PAVF following cerebral vein thrombosis (22), ischemia or hypoxia are important etiological factors. There is evidence that hypoxia is a powerful trigger for the up-regulation of angiogenic factors expression. (32)

\section{Main clinical and angiographical characteristics}

The majority of AVMs occurring in the neonatal and infant period are vein of Galen 
malformations. Nongalenic cerebral AVM (or pial AVM) have been reported to account for roughly $22 \%$ of AVMs found in neonates and $35 \%$ of AVMs in infants. (1) The common presentations in neonates are systemic cardiac manifestations (54\%), seizures (31\%), hemorrhage (15\%). In infants, hemorrhage (38\%), hydrodynamic disorders (38\%), cardiac manifestations $(16 \%)$ and seizures $(8 \%)$ are known to occur. (1)

PAVF produced in the first years of life can be associated with syndromes such as Rendu-Osler - Weber and KlipelTrenaunay-Weber síndromes. (33, 34) PAVF can cause headaches, hemorrhage, seizures, focal neurologic deficits, and raised intracranial pressure. (18)

Flow and perfusion pressure through a pial AV fistula is certainly high. Impaired venous drainage in AVMs has been implicated in the risk of hemorrhage, but whether venous varices accompanied by PAVF are associated with an increased risk of hemorrhage remains unclear. At present, four-vessel cerebral angiography is the gold standard diagnostic procedure which can distinguish nongalenic AVFs from AVMs. (35) Angiographic diagnostic criteria for AVFs consist of: (36)

1. Rapid circulation time because of high-velocity flow;

2. Enlarged feeding artery;

3. Direct filling of a large varix.

\section{Therapeutical approaches}

Therapeutic options of pial AVF include surgical excision of lesion, surgical ligation of feeder and endovascular obliteration of feeders. In addition to standard microsurgical technique, additional measures such as induced hypotension, temporary clipping and pharmacological neuroprotection may be helpful.

The anesthetic team should be ready in anticipation of severe blood loss and potential circulatory collapse, because preexisting venous hypertension may precipitate severe bleeding that does not respond to these and other standard hemostatic measures. The simple disconnection of the fistula should be the goal of therapy, (4) and attempts at excision of the varix may exacerbate parenchymal bleeding.

Hoh et al have summarized the literature from 1970 to 2000. There have been 79 patients reported to date. Venous varices were found in 48 of 54 cases (89\%). However, at that individual centre, only three out of nine were associated with varices. In their series, the concept of 'flowdisconnection' either endovascularly or surgically was advocated. (4) Surgical disconnection involves either aneurysm clip application or cauterization of the feeding vessel. Though this has been proven effective, some lesions are deep or surgically inaccessible and the risk of surgery can be very significant. As in this case, severe bleeding can be expected due to:

(1) venous hypertension due to the high-flow system and,

(2) hyperaemia from normal perfusion pressure breakthrough.

Unlike the case of nidus-type AVM, the strategy of surgical disconnection without lesion resection was found to be sufficient for obliteration of the fistula. Hence, excision of the varix is probably not required. (4)

\section{Endovascular approach}

PAVF are rare vascular lesions that require prompt treatment. As symptomatic patients managed conservatively have a 
poor prognosis, radical treatment should be undertaken as soon as possible. (37)

Obliteration of the fistula by an endovascular route, avoiding the risks associated with craniotomy, should always be considered especially when the lesion is deep seated or the risk of neurological deficit with surgery is high. $(4,19,38,39)$ Also should be considered the endoscopic intervention, that can be an effective and safe option for the treatment of this type of lesion.

Endovascular attempts are not always successful or safe. Several technical difficulties in obliteration of the fistula have been described. Endovascular embolization of the fistula may be complicated by migration of the embolization agent into a varix, to the lung or elsewhere in the cerebral vasculature. (4)

Newman et al., (40) described a novel endovascular treatment strategy that was used successfully to treat 2 pediatric patients with a PAVF, a single-channel high-flow PAVF was diagnosed in 2 male patients (6 and 17 years of age). Both patients were treated with endovascular flow arrest using a highly conformable balloon followed by Onyx infusion for definitive closure of the fistula. Neither patient suffered a complication as a result of the procedure. At the 6-month follow-up in both cases, the simple discontinuation of blood flow had resulted in durable obliteration of the fistula and stable or improved neurological function; thus, the authors conclude that Onyx can be delivered successfully into high-flow lesions after flow arrest to allow a minimally invasive and durable treatment for PAVF.

Paramasivam et al., (41) reported that development of de novo dural arteriovenous fistula(s) following endovascular embolization of a prior highflow PAVF is not an uncommon development. They are mostly asymptomatic and develop anywhere along the drainage of the fistula, maturing over time and diagnosed during follow-up studies, emphasizing the need for follow-up angiography. They can be effectively treated by endovascular embolization. Localized refractory dural fistulas can be dealt with by radiosurgery.

\section{Conclusions}

Intracranial arteriovenous fistulas are vascular malformations in which clinical suspicion and prompt diagnosis, with a subsequent appropriate therapeutic approach, are crucial to avoid the development of irreversible neurological damage or even patient death because these lesions can be associated with heavy bleeding and high mortality rates. Depending on their location and high-flow dynamics, these lesions can present treatment challenges for both endovascular and open cerebrovascular surgeons. Disconnection of direct shunting, either by endovascular or surgically, is sufficient to achieve successful treatment; therefore, total resection of the lesion is unnecessary. We propose a PAVF grading score, however a retrospective study is necessary to validate it. To our knowledge this is the first proposal for classifying PAVF based on evidence.

\section{Correspondence:}

Dr. Luis Rafael Moscote-Salazar, Universidad de Cartagena, Cartagena de Indias, Colombia. e-mail:mineurocirujano@aol.com 


\section{References}

1. Pillai A, Rajeev K, Unnikrishnan M. Surgical management of a pial arteriovenous fistula with giant varix in an infant. Neurol India [Internet]. 2006 Dec [cited 2013 Sep 8];54(4):434-6. Available from: http://www.ncbi.nlm.nih.gov/pubmed/17114861

2. Tabatabai SAF, Zadeh MZ, Habibi Z, Meybodi AT, Hashemi $M$. Intracerebral atypical calcification in nongalenic pial arteriovenous fistula: a case report. Cases J [Internet]. 2008 Jan [cited 2013 Sep 7];1(1):335. Available from: http://www.pubmedcentral.nih.gov/articlerender.fcgi?ar tid $=2605763 \&$ tool $=$ pmcentrez\&rendertype $=$ abstract 3. Passacantilli E, Pichierri A, Guidetti G, Santoro A, Delfini R. Surgical treatment of pial cerebellar arteriovenous fistulas with aneurysm of the main feeding artery. Surg Neurol [Internet]. 2006 Jan [cited 2013 Sep 7];65(1):90-4. Available from: http://www.ncbi.nlm.nih.gov/pubmed/16378872

4. Hoh BL, Putman CM, Budzik RF, Ogilvy CS. Surgical and endovascular flow disconnection of intracranial pial single-channel arteriovenous fistulae. Neurosurgery [Internet]. 2001 Dec [cited 2013 Sep 7];49(6):1351-63; discussion 1363-4. Available from: http://www.ncbi.nlm.nih.gov/pubmed/11846934

5. Nelson K, Lasjaunias P, Berenstein A. Endovascular embolization of congenital intracranial pial arteriovenous fistulas. Neuroimaging Clin $\mathrm{N}$ Am. 1992;2:309-17.

6. Lasjaunias P, Manelfe C, Chiu M. Angiographic architecture of intracranial vascular malformations and fistulas--pretherapeutic aspects. Neurosurg Rev [Internet]. 1986 Jan [cited 2013 Sep 7];9(4):253-63. Available http://www.ncbi.nlm.nih.gov/pubmed/3614684

7. Hetts SW, Keenan K, Fullerton HJ, Young WL, English JD, Gupta N, et al. Pediatric intracranial nongalenic pial arteriovenous fistulas: clinical features, angioarchitecture, and outcomes. AJNR Am J Neuroradiol [Internet]. 2012 Oct [cited 2013 Sep 10];33(9):1710-9. Available from: http://www.ncbi.nlm.nih.gov/pubmed/22766672

8. Kikuchi K, Kowada M, Sasajima H. Vascular malformations of the brain in hereditary hemorrhagic telangiectasia (Rendu-Osler-Weber disease). Surg Neurol [Internet]. 1994 May [cited 2013 Sep 8];41(5):374-80. Available from: http://www.ncbi.nlm.nih.gov/pubmed/8009411

9. Viñuela F, Drake CG, Fox AJ, Pelz DM. Giant intracranial varices secondary to high-flow arteriovenous fistulae. J Neurosurg [Internet]. 1987 Feb [cited 2013 Sep 8];66(2):198-203. Available from: http://www.ncbi.nlm.nih.gov/pubmed/3806202

10. Giller CA, Batjer HH, Purdy P, Walker B, Mathews D. Interdisciplinary evaluation of cerebral hemodynamics in the treatment of arteriovenous fistulae associated with giant varices. Neurosurgery [Internet]. 1994 Oct [cited 2013 Sep 8];35(4):778-82; discussion 782-4. Available from: http://www.ncbi.nlm.nih.gov/pubmed/7808630

11. Carrillo R, Carreira LM, Prada J, Rosas C, Egas G. Giant aneurysm arising from a single arteriovenous fistula in a child. J Neurosurg [Internet]. 1984 May [cited 2013 Sep 8];60(5):1085-8. Available from: http://www.ncbi.nlm.nih.gov/pubmed/6716144

12. Barnwell SL, Ciricillo SF, Halbach V V, Edwards MS, Cogen PH. Intracerebral arteriovenous fistulas associated with intraparenchymal varix in childhood: case reports. Neurosurgery [Internet]. 1990 Jan [cited 2013 Sep 8];26(1):122-5. Available from: http://www.ncbi.nlm.nih.gov/pubmed/2294462

13. Yang W-H, Lu M-S, Cheng Y-K, Wang T-C. Pial arteriovenous fistula: a review of literature. $\mathrm{Br} \mathrm{J}$ Neurosurg [Internet]. 2011 Oct [cited 2013 Aug 20];25(5):580-5. Available from: http://www.ncbi.nlm.nih.gov/pubmed/21501060

14. Valavanis A, Yaşargil MG. The endovascular treatment of brain arteriovenous malformations. Adv Tech Stand Neurosurg [Internet]. 1998 Jan [cited 2013 Sep 11];24:131-214. Available from: http://www.ncbi.nlm.nih.gov/pubmed/10050213

15. Lai CW, Agid R, van den Berg R, Ter Brugge K. Cerebral arteriovenous fistulas induced by dural arteriovenous shunts. AJNR Am J Neuroradiol [Internet]. 2005 May [cited 2013 Sep 11];26(5):1259_ 62. Available from: http://www.ncbi.nlm.nih.gov/pubmed/15891194

16. Pelz D, Lownie S, Fox A, Rosso D. Intracranial dural arteriovenous fistulae with pial venous drainage: combined endovascular-neurosurgical therapy. Can J Neurol Sci. 1997;24(7):210-8.

17. Lv X, Li Y, Jiang C, Wu Z. Endovascular treatment of brain arteriovenous fistulas. AJNR Am J Neuroradiol [Internet]. 2009 Apr [cited 2013 Sep 7];30(4):851-6. Available

from: http://www.ncbi.nlm.nih.gov/pubmed/19147710

18. Gonzalez LF, Chalouhi N, Jabbour P, Teufack S, Albuquerque FC, Spetzler RF. Rapid and Progressive Venous Thrombosis After Occlusion of High-Flow Arteriovenous Fistula. World Neurosurg [Internet]. 2012 Oct 24 [cited 2013 Sep 11]; Available from: http://www.ncbi.nlm.nih.gov/pubmed/23103261 19. Rodesch G, Malherbe V, Alvarez H, Zerah M, Devictor D, Lasjaunias P. Nongalenic cerebral arteriovenous malformations in neonates and infants. Review of 26 consecutive cases (1982-1992). Childs Nerv Syst [Internet]. 1995 Apr [cited 2013 Sep 8];11(4):231-41. Available from: http://www.ncbi.nlm.nih.gov/pubmed/7621485

20. Lasjaunias P. A revised concept of the congenital 
nature of cerebral arteriovenous malformations. Interv Neuroradiol [Internet]. 1997 Dec 20 [cited 2013 Sep 11];3(4):275-81. Available from: http://www.ncbi.nlm.nih.gov/pubmed/20678357

21. Ozawa T, Miyasaka Y, Tanaka R, Kurata A, Fujii K. Dural-pial arteriovenous malformation after sinus thrombosis. Stroke [Internet]. 1998 Aug [cited 2013 Sep 11];29(8):1721-4. Available from: http://www.ncbi.nlm.nih.gov/pubmed/9707217

22. Phatouros CC, Halbach V V, Dowd CF, Lempert TE, Malek AM, Meyers PM, et al. Acquired pial arteriovenous fistula following cerebral vein thrombosis. Stroke [Internet]. 1999 Nov [cited 2013 Sep 11];30(11):2487-90. Available from: http://www.ncbi.nlm.nih.gov/pubmed/10548689

23. Schmit BP, Burrows PE, Kuban K, Goumnerova L, Scott RM. Acquired cerebral arteriovenous malformation in a child with moyamoya disease. Case report. J Neurosurg [Internet]. 1996 Apr [cited 2013 Sep 11];84(4):677-80. Available from: http://www.ncbi.nlm.nih.gov/pubmed/8613863

24. Kader A, Goodrich JT, Sonstein WJ, Stein BM, Carmel PW, Michelsen WJ. Recurrent cerebral arteriovenous malformations after negative postoperative angiograms. J Neurosurg [Internet]. 1996 Jul [cited 2013 Sep 11];85(1):14-8. Available from: http://www.ncbi.nlm.nih.gov/pubmed/8683264

25. Batjer H, Samson D. Arteriovenous malformations of the posterior fossa: clinical presentation, diagnostic evaluation and surgical treatment. Neurosurg Rev [Internet]. 1986 Jan [cited 2013 Sep 8];9(4):287-96. Available from: http://www.ncbi.nlm.nih.gov/pubmed/3614687 26. Halbach V V, Higashida RT, Hieshima GB, Hardin CW, Dowd CF, Barnwell SL. Transarterial occlusion of solitary intracerebral arteriovenous fistulas. AJNR Am J Neuroradiol [Internet]. 1989 [cited 2013 Sep 7];10(4):747-52. Available from: http://www.ncbi.nlm.nih.gov/pubmed/2505503

27. Stapleton CJ, Armstrong DL, Zidovetzki R, Liu CY, Giannotta SL, Hofman FM. Thrombospondin-1 modulates the angiogenic phenotype of human cerebral arteriovenous malformation endothelial cells. Neurosurgery [Internet]. 2011 May [cited 2013 Sep 11];68(5):1342-53; discussion 1353. Available from: http://www.ncbi.nlm.nih.gov/pubmed/21307796

28. Kiliç T, Pamir MN, Küllü S, Eren F, Ozek MM, Black PM. Expression of structural proteins and angiogenic factors in cerebrovascular anomalies. Neurosurgery [Internet]. 2000 May [cited 2013 Sep 11];46(5):1179-91; discussion 1191-2. Available from: http://www.ncbi.nlm.nih.gov/pubmed/10807251

29. Rothbart D, Awad IA, Lee J, Kim J, Harbaugh R, Criscuolo GR. Expression of angiogenic factors and structural proteins in central nervous system vascular malformations. Neurosurgery [Internet]. 1996 May [cited 2013 Sep 11];38(5):915-24; discussion 924-5. Available

from:

http://www.ncbi.nlm.nih.gov/pubmed/8727816

30. Uranishi R, Baev NI, Kim JH, Awad IA. Vascular smooth muscle cell differentiation in human cerebral vascular malformations. Neurosurgery [Internet]. 2001 Sep [cited 2013 Sep 11];49(3):671-9; discussion 679_ 80. Available from: http://www.ncbi.nlm.nih.gov/pubmed/11523679

31. Rhoten RL, Comair YG, Shedid D, Chyatte D, Simonson MS. Specific repression of the preproendothelin-1 gene in intracranial arteriovenous malformations. J Neurosurg [Internet]. 1997 Jan [cited 2013 Sep 11];86(1):101-8. Available from: http://www.ncbi.nlm.nih.gov/pubmed/8988087

32. Shweiki D, Itin A, Soffer D, Keshet E. Vascular endothelial growth factor induced by hypoxia may mediate hypoxia-initiated angiogenesis. Nature [Internet]. 1992 Oct 29 [cited 2013 Aug 12];359(6398):843-5. Available from: http://www.ncbi.nlm.nih.gov/pubmed/1279431

33. Helmchen C, Nahser HC, Yousry T, Witt TN, Kühne D. [Therapy of cerebral aneurysms and arteriovenous vascular malformations in hereditary hemorrhagic telangiectasia (Rendu-Osler-Weber disease)]. Nervenarzt [Internet]. 1995 Feb [cited 2013 Sep 8];66(2):124-8. Available from: http://www.ncbi.nlm.nih.gov/pubmed/7715751

34. García-Mónaco R, Taylor W, Rodesch G, Alvarez $\mathrm{H}$, Burrows P, Coubes P, et al. Pial arteriovenous fistula in children as presenting manifestation of Rendu-OslerWeber disease. Neuroradiology [Internet]. 1995 Jan [cited 2013 Sep 8];37(1):60-4. Available from: http://www.ncbi.nlm.nih.gov/pubmed/7708192

35. Upchurch K, Feng L, Duckwiler GR, Frazee JG, Martin NA, Viñuela F. Nongalenic arteriovenous fistulas: history of treatment and technology. Neurosurg Focus [Internet]. 2006 Jan [cited 2013 Sep 11];20(6):E8. Available from: http://www.ncbi.nlm.nih.gov/pubmed/16819816

36. Tomlinson FH, Rüfenacht DA, Sundt TM, Nichols DA, Fode NC. Arteriovenous fistulas of the brain and the spinal cord. J Neurosurg [Internet]. 1993 Jul [cited 2013 Sep 11];79(1):16-27. Available from: http://www.ncbi.nlm.nih.gov/pubmed/8315463

37. Oshita J, Ohba S, Itou Y, Sakoda E, Ishihara S. [Case with intracranial pial arteriovenous fistulas]. No Shinkei Geka [Internet]. 2011 Dec [cited 2013 Sep 7];39(12):1197-202. Available from: http://www.ncbi.nlm.nih.gov/pubmed/22128276

38. Hermier M, Turjman F, Bozio A, Duquesnel J, Lapras C. Endovascular treatment of an infantile nongalenic cerebral arteriovenous fistula with cyanoacrylate. Childs Nerv Syst [Internet]. 1995 Aug 
DOI: 10.2478/romneu-2013-0018

[cited 2013 Sep 8];11(8):494-8. Available from: http://www.ncbi.nlm.nih.gov/pubmed/7585691

39. De Aguiar GB, Conti MLM, Veiga JCE, Jory M. Giant intracranial pial arteriovenous fistula treated by endovascular intervention. Minim Invasive Neurosurg [Internet]. 2011 Oct [cited 2013 Sep 10];54(5-6):247-9. Available from: http://www.ncbi.nlm.nih.gov/pubmed/22278788

40. Newman CB, Hu YC, McDougall CG, Albuquerque FC. Balloon-assisted Onyx embolization of cerebral single-channel pial arteriovenous fistulas. J Neurosurg Pediatr [Internet]. 2011 Jun [cited 2013 Sep 10];7(6):637-42. Available from: http://www.ncbi.nlm.nih.gov/pubmed/21631202

41. Paramasivam S, Toma N, Niimi Y, Berenstein A. De novo development of dural arteriovenous fistula after endovascular embolization of pial arteriovenous fistula. J Neurointerv Surg [Internet]. 2013 Jul [cited 2013 Sep 10];5(4):321-6. Available from: http://www.ncbi.nlm.nih.gov/pubmed/22510457 